\title{
Mouse inoculation for the detection of non-cultivable gastric tightly spiralled bacteria
}

\section{E.N. Mendes ${ }^{1}$, \\ D.M.M. Queiroz ${ }^{1}$, \\ S.B. Moura ${ }^{2}$ and \\ G.A. Rocha ${ }^{1}$}

\author{
${ }^{1}$ Laboratório de Pesquisa em Bacteriologia, Faculdade de Medicina, \\ and ${ }^{2}$ Departamento de Microbiologia, Instituto de Ciências Biológicas, \\ Universidade Federal de Minas Gerais, Belo Horizonte, MG, Brasil
}

\begin{abstract}
Correspondence
D.M.M. Queiroz

Laboratório de Pesquisa em

Bacteriologia

Faculdade de Medicina, UFMG

Av. Alfredo Balena, 190/4026

30130-100 Belo Horizonte, MG

Brasil

Fax: 55 (031) 274-2767

Research supported by CNPq, FAPEMIG, PRPq/UFMG and FINEP.
\end{abstract}

Received June 30, 1997

Accepted January 12, 1998

\section{Abstract}

In the present study we compared the inoculation of swine gastric mucus into the stomach of mice, the urease test and carbolfuchsinstained smears for the diagnosis of the infection with "Gastrospirillum suis" ("Helicobacter heilmannii" type 1), an uncultivated tightly spiralled gastric bacterium. Fragments obtained from the antral and oxyntic mucosa of the stomach of 50 slaughtered pigs were used for urease test, for carbolfuchsin-stained smears and for obtaining scrapings of mucus for mouse inoculation. The mice were killed by spinal dislocation 10 days after inoculation and fragments of the antral and oxyntic mucosa were used for spiral bacterium identification (urease test and carbolfuchsin-stained smears). Among the methods employed for the diagnosis of " $H$. heilmannii" infection, the inoculation of gastric mucus into the stomach of mice was the most sensitive and demonstrated bacterial positivity in $31(62.0 \%)$ swine. Direct examination showed tightly spiralled bacteria in the gastric mucosa of only $4(8.0 \%)$ of the 50 pigs studied. Among them, $3(6.0 \%)$ presented a positive preformed urease test. Spiral bacteria were not seen in the gastric mucosa of any control mice. These results show that the use of the mouse inoculation method improved the detection of " $H$. heilmannii" in swine.
Although spiral bacteria have been observed in the stomach of animals since the end of the 19th century $(1,2)$, the interest in gastric bacteria has increased only after the isolation of Helicobacter pylori from the gastric mucosa of human patients with gastritis and peptic ulcer. Since then, several spiral organisms have been described in the gastric and intestinal mucosa of man and other animals (3). Among them, a tightly spiralled bacterium, named "Gastrospirillum hominis", was described by Dent et al. (4)

\section{Key words}

- Helicobacter

- "Helicobacter heilmannii"

- "Gastrospirillum"infection diagnosis

- Gastric spiral bacteria

- Helicobacterinfection diagnosis

- Mouse inoculation and McNulty et al. (5) in the stomach of patients with gastritis and peptic ulceration. Recently, 16S rRNA sequencing studies have demonstrated that this bacterium, in fact, represents at least two new species in the genus Helicobacter: "H. heilmannii" type 1 and " $H$. heilmannil" type 2 (6). Another organism, morphologically similar to " $H$. heilmannii" and provisionally named "Gastrospirillum suis", has been observed in the gastric mucosa of swine (7-9). More recently, it was shown that this bacterium is 
also a Helicobacter and is $99.5 \%$ similar to "H. heilmannii" type 1 . This level of similarity indicates that " $H$. heilmannii" type 1 and "G. suis" are members of a single species and allowed us to hypothesize that pigs could be a reservoir host for human " $H$. heilmannii" type 1 infection (10).

Several methods have been used for diagnosing the presence of helicobacters in the gastric mucosa of man and other animals. Among them, rapid methods such as the urease test and several staining procedures have been used for presumptive diagnosis (11). Of the methods involving collection of tissue fragments, however, culture is, in experienced hands, one of the most sensitive for detecting some helicobacters, especially H. pylori. Despite several attempts, however, culture of tightly spiralled bacteria in artificial media has not been successful, except for H. felis (12) and H. bizzozeroni (13). For this reason, the diagnosis of the presence of these organisms has been based on methods such as the urease test and examination of stained smears and histological sections $(7,9,14,15)$. Based on early studies by Salomon (2), Dick et al. (14) have proposed the inoculation of mice with scrapings of gastric mucus as a way of maintaining and isolating these organisms in vivo. Using the same method, Moura et al. (15) have succeeded in colonizing mouse stomach with "H. heilmannii" type 1 employing scrapings of the gastric mucosa of bacterium positive swine.

Although urease test, stained smears and histological sections of gastric mucosa have been widely used for the diagnosis of infection with uncultivated tightly spiralled bacteria, especially in humans $(14,16)$, the accuracy of these methods and gastric mucus inoculation into the stomach of mice has not yet been evaluated.

For these reasons, we undertook the present study in order to compare the inoculation of gastric mucus of swine into the stomach of mice, the urease test and the carbolfuch- sin-stained smears, as suitable methods to detect the presence of non-cultivable helicobacters in the gastric mucosa of swine.

In the first part of this study, stomachs of 50 consecutive pork-weight pigs, slaughtered at about 6 months of age, were studied. The organs were opened longitudinally along the greater curvature and thoroughly washed with tap water. One tissue sample (about $15 \mathrm{~cm}^{2}$ ) was then taken from the gastric antrum in the lesser curvature at approximately $2 \mathrm{~cm}$ from the torus piloricus, and another fragment of the same size was obtained from the oxyntic mucosa in the greater curvature of the stomach, for microbiological examination and inoculation into the stomach of mice. The fragments were transported to the laboratory in individual bags.

Fragments of approximately $1 \mathrm{~cm}^{2}$ were removed from the antral and oxyntic mucosa samples, obtained as described before, and used for identification of spiral bacteria (urease test and carbolfuchsin-stained smears). Approximately half of each fragment was placed in a tube containing Christensen's urea broth to detect preformed urease (7). The other half was blotted on a piece of filter paper to remove surface mucus and then smeared on a glass slide, heat fixed and stained with carbolfuchsin (7).

Scrapings of both remaining fragments of the antral and oxyntic mucosa from each pig were homogenized in the same flask containing 3 parts of $0.85 \%$ saline and $0.2 \mathrm{ml}$ of the mixture was inoculated with a sterile stomach tube into two 4-6-week-old gastric spiral bacteria-free BALB/c male mice. Each group of animals was maintained under the same conditions in separate cages and had free access to water and to commercial pelleted diet. The control group, consisting of 20 4-6-week-old BALB/c male mice, was inoculated with $0.2 \mathrm{ml}$ of $0.85 \%$ saline and maintained under the same conditions as described above, in groups of 5 animals. The animals were killed by spinal dislocation 10 days after inoculation. The stomachs were 
removed, opened along the greater curvature and washed in sterile $0.85 \%$ saline. Fragments of the antral and oxyntic mucosa were taken for microbiological examination as described above.

In the second part of the sudy, in order to investigate if the sensitivity of the methods employed could be influenced by the uneven distribution of the microorganism, we took four fragments of approximately $1.0 \times 2.0$ $\mathrm{cm}$ from the antral, oxyntic and cardiac regions of the stomach of 10 swine. Two fragments of the antrum were obtained along the lesser curvature at about $2 \mathrm{~cm}$ from the torus pyloricus and the other 2 along the greater curvature. All fragments of the gastric body were obtained along the middle portion of the greater curvature. The fragments of the cardiac mucosa were obtained in the upper portion of the greater curvature $(\mathrm{N}=2)$ and adjacent to the pars esophagea $(\mathrm{N}=2)$. One third of each fragment was used for the urease test, one third for the preparation of carbolfuchsin-stained smears, and the remaining fragment was ground in a tissue grinder, homogenized in 3 parts of saline and inoculated into the stomach of 2 gastric spiral bacteria-free $\mathrm{BALB} / \mathrm{c}$ male mice.

Among the methods employed for the diagnosis of " $H$. heilmannii" type 1 infection, the inoculation of gastric mucus into the stomach of mice was the most sensitive and demonstrated bacterial positivity in 31 $(62.0 \%)$ swine. Among the mice inoculated with mucus from the 31 " $H$. heilmannii" type 1 positive pigs the bacterium was seen in the antrum and corpus of 22 , only in the antrum of 4 , and only in the corpus of 5 . The urease test was positive in gastric fragments from $3(6.0 \%)$ pigs and tightly spiralled bacteria were observed in carbolfuchsin-stained smears of the antral and oxyntic mucosa of 4 $(8.0 \%)$ animals. Although the direct examination and urease test were less sensitive, in no instance were their results in disagreement with those of inoculation into the stomach of mice, i.e., when their results were positive the inoculation into mice was also positive. Tightly spiralled bacteria were not found in the antral or oxyntic mucosa of any control animal.

In the second part of the study, the mouse inoculation method detected the organism in the stomach of $8(80 \%)$ swine. The urease test and the examination of carbolfuchsinstained smears were positive in $2(20 \%)$ swine: in one pig, both tests were positive in the same fragment obtained from the body of the stomach and, in the other, the urease test was positive in 3 fragments of the oxyntic region and the carbolfuchsin-stained smears were positive in 2 fragments of the antrum.

The diagnosis of the gastric tightly spiralled bacterium infection in both man and other animals has been made by the urease test and by the examination of smears and histological sections of gastric mucosa stained by several methods $(7,9,14,15)$ depending on availability and on the preference of each author. The results of these methods, however, are dependent on the number and distribution of organisms in the gastric mucosa. In fact, it has been determined that detection of bacteria in general by direct examination is positive only when the number of organisms $/ \mathrm{ml}$ is higher than $10^{4}(17)$. In regard to the urease test, it was demonstrated for the diagnosis of $H$. pylori infection that the test may be negative when the number of viable bacteria is less than $10^{4}$ (18). The present results show that the inoculation of mice with scrapings of gastric mucosa was more sensitive than either the urease test or direct examination for the diagnosis of " $H$. heilmannii" type 1 infection in pigs. The uneven distribution of the organisms within the gastric mucosa could alter the sensitivity of the methods due to sampling error but the use of scrapings of gastric mucosa for mouse inoculation in this study may have overcome the possible irregular distribution of the organism in the stomach. Also, the use of two mice and the examination of both the antral and oxyntic 
mucosa of each animal further improved the diagnostic sensitivity.

The results of the second part of the study further confirmed that the mouse inoculation was the most sensitive method and the use of several fragments from different regions, which could reduce the problem related to the uneven distribution of the microorganism, did not increase the sensitivity of the direct examination of smears and of the urease test. The higher sensitivity of the mouse inoculation method is probably due to the predisposition of mice to be colonized by gastric tightly spiralled bacteria, even when their number is low.

We conclude that the inoculation of mice with gastric mucus is the most sensitive method available thus far for diagnosing " $H$. heilmannit" type 1 infection in pigs. Since "H. heilmannii" type 1 also colonizes human gastric mucosa $(10,18,19)$ the method could be used for the diagnosis of the infection in humans. In fact, Dick et al. (14) have reported heavy colonization of the stomach of mice inoculated not only with mucus scraped from the stomach of a monkey but also with biopsies obtained from the gastric mucosa of a man.

Our results showed an improvement in the detection of "H. heilmannii" in swine, suggesting that the procedure we used in this study could also improve the diagnosis of uncultivated gastricHelicobacter in the stomach of mammals.

\section{References}

1. Bizzozero G (1893). Ueber die Schlauchformigen Drusen des Magendarkanals und die Bezeinhungen ihres Epithels zu dem ober Flachenepithel dur Schleimhant. Archiv für Mikrobiologie Anatomie, 42: 82.

2. Salomon $H$ (1896). Ueber das Spirillum des Saugetiermagens und sein Verhalten zu den Gelegzellen. Zentralblatt für Bakteriologie Mikrobiologie, 16: 151-155.

3. Goodwin CS \& Worsley BW (1993). Microbiology of Helicobacter pylori. Gastroenterology Clinics of North America, 22 : 5-19.

4. Dent JC, McNulty CAM, Uff JS, Wilkinson SP \& Gear MWL (1987). Spiral organisms in the gastric antrum. Lancet, 2: 96.

5. McNulty CAM, Dent JC, Curry A, Uff JS, Ford GA, Gear MWL \& Wilkinson SP (1989). New spiral bacterium in gastric mucosa. Journal of Clinical Pathology, 42: 585-591.

6. Solnick JV, O'Rourke J, Lee A, Paster B, Dewhirst FE \& Tompkins LS (1993). An uncultured gastric spiral organism is a newly identified Helicobacter in humans. Journal of Infectious Diseases, 168: 379385.

7. Queiroz DMM, Rocha GA, Mendes EN, Lage AP, Carvalho ACT \& Barbosa AJA (1990). A spiral microorganism in the stomach of pigs. Veterinary Microbiology, 24: 199-204.

8. Mendes EN, Queiroz DMM, Rocha GA,
Moura SB, Leite VHR \& Fonseca MEF (1990). Ultrastructure of a spiral microorganism from pig gastric mucosa ("Gastrospirillum suis"). Journal of Medical Microbiology, 33: 61-66.

9. Mendes EN, Queiroz DMM, Rocha GA, Nogueira AMMF, Carvalho ACT, Lage AP \& Barbosa AJA (1991). Histopathological study of porcine gastric mucosa with and without a spiral bacterium ("Gastrospirillum suis"). Journal of Medical Microbiology, 35: 345-348.

10. Mendes EN, Queiroz DMM, Dewhirst FE, Paster BJ, Rocha GA \& Fox JG (1994). Are pigs a reservoir host for human Helicobacter infection? American Journal of Gastroenterology, 89: 1296 (Abstract 45).

11. Glupczynski $Y$ \& Hirschl AM (1994). Diagnosis. In: Malfertheiner $P$, Mégraud $F$, Michetti P \& Price A (Editors), The Year in Helicobacter pylori - 1994. Current Science Ltd., London, 12-16.

12. Lee A, Hazell SL, O'Rourke J \& Kouprach $S$ (1988). Isolation of a spiral-shaped bacterium from the cat stomach. Infection and Immunity, 56: 2843-2850.

13. Hanninen ML, Happonen I, Saari S \& Jalava K (1996). Culture and characteristics of $H$. bizzozeronii, a new canine gastric Helicobacter sp. International Journal of Systematic Bacteriology, 46: 160-166.

14. Dick $E$, Lee $A$, Watson $G$ \& O'Rourke $J$ (1989). Use of the mouse for the isolation and investigation of stomach-associated, spiral-helical shaped bacteria from man and other animals. Journal of Medical Microbiology, 29: 55-62.

15. Moura SB, Queiroz DMM, Mendes EN, Nogueira AMMF \& Rocha GA (1993). The inflammatory response of the gastric mucosa of mice experimentally infected with "Gastrospirillum suis". Journal of Medical Microbiology, 39: 64-68.

16. Heilmann KL \& Borchard F (1991). Gastritis due to spiral shaped bacteria other than Helicobacter pylori. clinical, histologi$\mathrm{cal}$, and ultrastructural findings. Gut, 32 : 137-140.

17. Tarshis MS (1970). The mycobacteria. In: Frankel S, Reitman D \& Sonnenwirth AC (Editors), Gradwohl's Clinical Laboratory Methods and Diagnosis. Vol. 2. CV Mosby Co., St. Louis, 1233-1268.

18. Resende LMH, Queiroz DMM, Mendes EN, Rocha GA, Coelho LGV, Passos MCF, Castro LP, Oliveira CA \& Lima Jr GF (1993). Comparison of the urease test and of direct smear examination in the control of treatment of Helicobacter pylori-induced infection. Brazilian Journal of Medical and Biological Research, 26: 699-702.

19. Deltenre M, Glupczynsky $Y$, de Prez C, Nyst JF, Burette A, Labbé M, Jonas C \& Dekoster E (1989). The reliability of urease test, histology and culture in the diagnosis of Campylobacter pylori infection. Scandinavian Journal of Gastroenterology, 24 (Suppl 160): 19-24. 